\section{Archæological Excavations at Colchester}

Sxstematic archæological excavation on the central part of the site of the ancient British city at Colchester must, it is announced, cease permanently at the close of October, when this area of some twenty acres is to be developed for building. It will be remembered that the discovery of a British settlement here was made eight years ago in the course of preparations for the Colchester by-pass road; and that since that date, with the co-operation of the local authorities, a Committee of Excavation, under the auspices of the Society of Antiquaries of London, has been engaged in the archæological exploration of the site. Not only has the defensive system been investigated, but also a very large number of antiquities, estimated at something in the neighbourhood of a million, and including fifty tons of pottery, has been recovered. This site has, in fact, proved one of the most prolific of ancient British sites yet examined. The central area now under examination, it was hoped, would afford some evidence of the place of residence of the British king, Cunobelinus; but so far nothing of this nature has come to light. Among the more important objects recently reported in the present season's work are an iron box four inches square and one and a half inches deep. This contains a powder believed to be a pigment used by the potter. A Roman dagger, 15 in. long, has also been found. Although systematic investigation must cease as soon as building operations begin, local members of the Committee will continue to oversee the work of foundation-digging in the interests of archæology.

\section{Burials of Saxon Age in Kent}

ONE of the most important discoveries of burials of Saxon age in recent years is recorded from Risley, Horton Kirby, four miles south of Dartford, in Kent. In the course of road-making on the housing estate of the District Council, burials were brought to light in which were human bones, spear-heads, the umbo of a shield, pottery fragments, and an almost complete glass vessel. Fortunately the finds were brought to the notice of the Dartford Antiquarian Society, and their character as Saxon or Jutish recognized. Further excavation made it evident that this was the site of an extensive cemetery, although another, excavated in 1867, existed only a mile away to the north. That the present site had been in use for burial purposes even before Saxon times was indicated by a Roman cinerary urn and a circular cist burial. The prevalence of inhumation points to a Jutish origin, the period of the burials being from the sixth to the ninth centuries of our era. The people must have been of exceptionally fine physique, as a number of the skeletons are those of men more than six feet in height. So far more than seventy graves have been exposed. The burials as a rule are shallow, not more than two feet deep. In one instance only have valuables been found-in the grave of a woman, in which were five gold brooches and four beads of amethystine quartz. The brooches, it is stated in a report on the excavations in The Times of September 16, were circular, of filigree work, with precious stones inset, and represent a style of ornament peculiar to
Kent, of which this is the westernmost example. One fine burial of a warrior with shield-umbo, sword and spear, is to be removed and reassembled complete, with the bones, for exhibition. The excavations are being continued on a part of the site which is to be set aside as an open space. A selection of the finds has been on view in the Dartford Borough Museum.

\section{Meare Lake Village}

The three habitations (Nos. xx, xxii and xxiv), which have been examined by Mr. H. St. George Gray and Dr. Arthur Bulleid in the course of the current season's investigation of the eastern division of Meare Lake Village, Somerset, by the character of the finds, more particularly those in hut No. xxii, have emphasized both the importance of the weaving industry in the economy of the inhabitants, and their appreciation of personal ornament of a colourful type. In hut xxii, in which five superimposed hearths of stone and clay have been uncovered, no fewer than twelve combs for beating down the weft and woof threads have been found, with bobbins, loom weights and a dozen spindle-whorls of stone, bone or baked clay. Among other finds were half a dozen saddle querns, hammer-stones and whetstones, a polished flint axe converted into a hammer, flint scrapers, bone awls and modelling tools, iron tools, bone gouges and handles and other objects of red and roe-deer antler, including a 'gaming piece'. A scapula, or shoulder-blade of ox, is ornamented with the dot-andcircle pattern. By far the largest series of remains, however, it is stated in a report on the excavations in The Times of September 16, may be classed as personal ornaments. These include two toggles or dressfasteners, one finely engraved with four rows of dotand-circles, the other of a zoomorphic character, having one end resembling the head of a fish. A remarkable large flat brooch is of bronze, of which the surface was probably inlaid with enamel. The finest of the armlets of Kimmeridge shale is carved, while jet appears in the village for the first time in the form of a bead. Another bead of amber has been found, and beads of glass are numerous, the colours being blue, dark red, yellow and black. Some of the beads of clear glass ornamented with yellow spirals were found in a group. The smallest beads (blue) are only two millimetres in diameter. Canine teeth of the dog had been pierced for suspension as a necklace. In hut xxii more pottery, mostly cooking wares, has been found than in any other dwelling.

\section{Twenty Years of Polish Science}

When Poland regained its independence in 1918, a new impetus was given to Polish science and culture, which had had to struggle against adverse conditions for so long. The present year marks the completion of twenty years of constructive achievement in many directions. Much that has been achieved in general science has been recorded in Nauka Polska, a comprehensive publication issued at least once annually by the Mianowski Institute for the Encouragement of Science in Poland, which is concerned with the history, organization and 